\title{
Writing matters in leadership practice
}

Louise M. Thomas, Education Consultant and Honorary Fellow of Australian Catholic University (ACU), email: louisethomas16@gmail.com

Anne B. Reinertsen

Queen Maud University College, abr@dmmh.no

\begin{abstract}
:
This is an attempt to rethink, ultimately forethink, leadership as a collaborative process of writing and what we think leadership might look like in the $21^{\text {st }}$ century. We try to move beyond leadership taking into account complex relations that shape emergent processes of organizing and change. It is a move away from ideas of individual agency and control. Traditional concepts of hierarchy, selective application, linearity and rationality are no longer appropriate. We offer different shades and elaborations. None are complete or finished. The authority of the reader and audience is pivotal. Through multiple engagements with writing we hope to offer glimpses of powerful leadership.
\end{abstract}

Key words: Beyond leadership. Materiality of language. Leadership as collaborative (wr)iting processes.

\section{Introduction plus:}

Words (I saw them with my eyes when I was three years old) are our dwarfs, our gnomes, our minuscule workers in the mines of language. They perforate our deafness. They forethink. And at times they are the Scandinavian tomtes or else the imps. Naturally they know what goes on in the more or less well-tended corners of the back of our mind. As everyone wants not to know, we have all the words we deserve. These little so ancient agents never stop joking and bringing us gifts in secret. Too bad for those who consider words to be worn down pebbles... (Cixous, 2005, p.121).

The law and the word decide what is, but they must both be put to work so the world won't freeze in what it is. We love words. We love to word. We write words. Words write us. We write things. Things write us. We write leadership. Leadership writes us. Words, things and leadership write. We love writing words, things and leadership. We make matter and sculpture with words. The making of words, writing, matters and the matter of writing, words, matter. We want to deserve more. That is our materialist and vitalist, embodied and embedded no-ology deleuzoguattarian desire, and it positions where we here and now write from: "We believe in desire as the irrational of every form of rationality, and not because it is a lack, a thirst, or an aspiration, but because it is the production of desire: desire that produces - real desire, or the real in itself" (Deleuze \& Guattari, 2004, p. 414). So from where we start, what matters and real desire, our take on writing works to enable a move from leadership which is hermeneutic in its practice to leadership which is enacted as immanence, where leader/leadership is constantly becoming, becoming rather than a fixed point of 'is-ness' driven by expectations of practice. Leadership, at-work in this becoming way, allows for a move from normative to analytical diffractive pedagogies. Writing such becomingness is both poetic and politic; 
enabling, through writing, an ethics of leadership as a micro political arena simultaneously stretching (Janesick, 2016) and strengthening every slippery step of processes of diffractive possibility creation.

Words are slippery. They dig deep, they surface, they layer, they sculpt, flow, float and move along. It is wonderful writing to enable nothing but uncertain possibilities with which we both continue to create ways to think, speak and do leadership. Words/we can move or be moved in and out of institutions, of cultural contexts - of structures, - of grammar, of institutional and cultural expectations and demands (see Henderson, Horan \& Loch, 2016 - in this journal). They/we can construct, deconstruct, reconstruct and co-construct. They/we can produce, reproduce, and coproduce. Slippery, slipping words write constructions and productions: constructions and productions, which are always already fluid, floating, deep, superficial, layered, and segmented. Writing words construct, produce, reconstruct, reproduce and co-construct leadership. Writing, thus sculpturing leadership constructions, is what we try to do, moving from personal ethic to political ethic through the act/art of writing. With this, we think of our writings as po/etic (poetic/political po-etic/litical ethics) and 3D multidimensional (Reinertsen, 2015a) micro ontologies of selfmaking or process ontological "thinking territories" (Deleuze \& Guattari, 2013, p. 44). Writing eroding, sculpturing, possibilizing every/anything always: poetry and politics becoming an ethics of constantly building in perhapses, and never 'is-ness', in every word. In this way, "(w)riting has nothing to do with meaning. It has to do with landsurveying and cartography, including the mapping of countries yet to come" https://www.goodreads.com/author/quotes/13009.Gilles Deleuze

Language and writing matters are embodied not through certainty of meaning but through the possibilities and constant becomingness of words 'yet to come' in the constant relationality between self and other. In the same way that Deleuze and Guattari (2004) write from a position of "Body without Organs", we work with concepts of language and writing to construct 'without' as the most meaningful nonsense constantly activating difference. These are thus processes of no-sense or asignifying, semiotic diffractions always diffracting differently, thus putting - together - apart and "of the void" (Barad, 2012, p. 13): words without meanings, thus of the void.

We do this with a tentative hold on the concept of language matters "as dynamic and shifting entanglements of relations" (Barad, cited in Jackson \& Mazzei, 2012, p. 115). The material produced through these entanglements (i.e. writing) is dynamic and is mutually constituted between the human (the writers) and the non-human (the words). The translations and transductions we make in writing matter, the words and languages we write and writing matter, matter. Writing and language, without meaning fixed by words and constant in their becomingness, matter.

And to elaborate further: never neutral, never innocent words and language are ideologically laden (Pelias, 2013, p. 559); and as such language in translation is culturally and contextually slippery. Thus we, as co-writers, do not, - cannot -, write from and with shared meanings or understandings of words and languages and leadership. Writing across multi-contextual experiences is complex and challenging. As authors/researchers, we both write particular texts, resisting representation. We write languages. Languages write us. Both trapped in our contextual oxygen but free to breathe. In this text, we think speak and write across different language contexts to report on writing as a leadership tool in early childhood education and care (ECEC) organizations. Central within these writings is a desire to expand and increase the depth of our analytical writing practices. We enact this desire as we write about leadership writing processes and practices that work to resist normative pedagogies and ways of doing leadership. We try to both make sense/non-sense and resist the constraint of an imposed expectation of sense-making, as we construct/deconstruct/reconstruct, i.e. disrupt and connect "with our separate and together thinking and wonderings" (MacLure, 2013, p. 660). Always expanding thus increasing and deepening our theorizing and analytical awareness about our own agendas, our own ideologically laden words, linked to responsibility and ethics, we take on board the material consequences of our constructed, and ever changing knowledges and work with 
what Barad refers to as an ethic of knowing (cited in Jackson \& Mazzei, 2012) - a response-ability. Writing, for us, is both ultimately and tentatively positioned as a method for democratization of both research and leadership, and in this case leadership research. As such it allows more voices to speak and allows for a more democratic listening to both self and other - multi response-abilities. In this way making both research and leadership more robust because they are real in themselves and work through language as becoming "agentical - realists - realism/s" (Barad, 2007, p. 133-185): i.e. becoming leadership practices which assign agency to words and writing. Writing positioned as an embodiment of language, as constructed knowledge: language thus words / thus writing / thus language... language/writing... writing languages has the ability to respond and can be both ethics and politics at a local level. Writing both enables and constrains a mutually constitutive, and never fixed, embodiment of meaning-making - in this instance, never fixed leadership meaning-making that is constantly becoming and never fixed, through words and language.

The law and the word decide but, through being put to work as writing, both are turned into tools and/or methods for using ourselves as thinkers and questioners, and what we think and question about is leadership. Sliding doubts and questions into the material (the matter of language: words) is our strategic grip, thus we write to respond, to open up opportunities for deeper minuscule questions to allow for undecidability and constant becomingness: doubts and questions that enable and constrain leadership and leadership identity construction as analytical enactments. We therefore position writing as a methodological element of leadership and /or leadership identity practice and research. And to be clear; we view writing as a link between leadership as analytical practices and pedagogical practices. Writing is seen as a transgressive tool and method for working with and against knowledge and knowing: knowledge, knowing, and not-yet-knowing of self and other. The aim in using writing in this way is not finding truth in this knowledge and knowing, but being in analytic, fluid and creative processes of writing: opening up for multiplicities, complexities and play (Richardson \& St Pierre, 2005) and possibilities. Writing thus is positioned as a trigger available to the analytic work of leaders. Writing, as a creative analytic function, gives life to notions, memories and feelings; it triggers recognitions and possibilities. It triggers unknowings and not-yet-knowns and constant erosions. It triggers possibility moments of allowing thinking other.

Writing privileges, and challenges critical self-reflection; we position writing as thinking tool (Richardson \& St. Pierre, 2005) or, because we like it, writing as consciously negative, non-certain and non-sensical; thinking, doubting, hesitating and keeping this ... "Negativitetens saar aabent" / "Wound of negativity open" (Kierkegaard, 1994, p. 81). We engage in language/writing in a search for meanings, meanings that are never fixed or certain, but which are constantly constructed and reconstructed in engagements between self and other (both human and non-human other). We can only be available to these meanings if we remain open to the negativity/uncertainty, non-sense of not knowing in the search for knowing. Come aporia/Derrida. Writing matters in leadership practices.

The gift, if there is any, requires and at the same time excludes the possibility of narrative. The gift is on condition of the narrative, but simultaneously on the condition of the possibility and impossibility of the narrative. (Derrida, 1992, p. 103)

And to sum up before we go on, this article is about our attempts to think, speak and write across different language contexts to report on writing as a leadership tool in ECEC organizations and the possibility of educational leadership becomings in the research process. Our work here is about embodiment and deterritorialization of knowledge and knowing. Central is a wish to expand and increase the depth of our analytical practices, to draw on writing practices and our analysis of writing matters to question our certainties and allow our uncertainties. We first introduce some data in the form of leadership erosions. Both examples are from ECEC organizations using writing as tools and methods to think with and about leadership practices and identities. These erosions are also woven across our own writing about writing to provide a sense of the complexity of such processes. Next is 
a section on what we call minor multilingual leadership writing. We write here to position ECEC organizations as translocal and corpovirtual spaces and ECEC leadership (and through leadership the becomingness of childhoods) as a matrix of becoming. Corpovirtuality implies an aporetic loss of self because we lend (gift) ourselves to the other. It is a looking towards the future fabulation anchored in vulnerability, response-ability and commonality. We then move on from here to position both writing and leadership as both becoming and performance; and such becomingness/performances as gifts that are never certain in their giving but open to possibilities available through an acceptance of uncertainties and the not-yet-knowing of self and other and practice. We might speak of rhizomatic leadership and leadership moments... As we go along we draw on the storying of our collaborating ECEC leaders and practitioners to try to open up our thinking and theorizing about writing and make visible glimpses of powerful ECEC leadership at work in and through analytical and constant becoming writing practices. We examine how such writing practices may build ECEC practice that go beyond a normative privileging of critical reflection. The storying presented in the following sections positions our collaborators as they engaged with the normative expectation of engagement in 'critical reflection' as a practice of effective early childhood leadership. We write our desire to push beyond an expectation of 'critical reflection' and to open up/to a possibility of diffractive practice in the constant becoming of leadership being and doing.

\section{Leadership erosions from Norway}

This storying belongs to an in-service counselor and leader in an ECEC organization. Sixty professionals are employed in this ECEC organization and they are all organized in writing groups. The groups meet once every month and discuss their own writing stories. The counselor organizes and leads all meetings.

I am uncertain whether it is counseling or different leadership processes that happen. As counsellor I create new approaches unknown to many encouraging critical reflection rather than just reflection. I think of myself as leader in counseling and that I lead critical reflection processes. And I need to dare facing that the future is open for us (Interview with ECEC leader, Holly, 10.09.15).

As we see, theorizing leadership stands out as an urge but in tensions between leading and counseling, freedom and control, individual and collective, internal and external processes. In these tensions, writing has become their practices, theories, strategies and methods for knowledge creation and learning. The ECEC organization has become a writing organization (Rhodes, 2003, Reinertsen, 2015) for learning.

Read more as we move along together.

\section{Leadership erosions from Australia}

This storying belongs to four early childhood educators who are part of a team of EC leaders/managers from a large early childhood organization. The team participated in a professional learning program in which their stated goal was to enhance their critical reflection on their individual and group professional identities as leaders. The program provided participants with individual, guided discussions with a facilitator. Elements of these conversations were written up and anonymous extracts shared with the group, together with a series of prompting questions to enhance critical reflections. My involvement in the project was as facilitator of the process and researcher of leadership identity constructions. As part of the project participants were asked to write their reflective comments in response to the anonymous extracts. This led to collaborative writing work on the ways in which, as a team, the group could enhance their ongoing engagement 
with processes of constant questioning and re-thinking their work as early childhood leaders. This was followed by individual journal writing and a follow up individual guided discussions to reflect on the process.

Writing, done as collaborative supported processes - 'writing conversations', was used to enable a flow between individual thinking and questioning and group thinking and questioning and back again. A series of individual conversational interviews involved asking questions to challenge takenfor-granted discourses of professional identity and leadership practices - i.e. challenging assumed ways of thinking, speaking and doing professionalism and leadership:

I think the individual conversations with you were very helpful for me because I think you have a way of asking questions that enables (me) to think outside of my standard responses and way of thinking. ... helps to prompt your thinking beyond just 'Oh I know the response to that.. this is what I say when people ask me about leadership' (Interview with ECEC leader, Nel, 18.2.15)

Key extracts of individual interviews were written up highlighting binaries within statements made by individuals, contradictions and hesitations evident in participants' language. Some examples:
Am I doing a 'good job'?/What is a 'good job'?
$(I ' m)$ expected to 'know the answers'/sharing my uncertainty
What you want the role to be/what you know it has to end up being Importance of 'team'/wanting to be a 'loner' - is there room for individuality?
Pushing others out of their comfort zone/resisting doing this myself
My professional identity/it's not just about me

The full list of extracts, showing over twenty different dichotomies, was written and presented to the participants in a subsequent whole group session. They were given time to read through and reflect on these statements and were then asked to write individual comments on each of the statements. These statements were collated into one written document and these were sent to the participants for further reflection and as a mechanism to trigger their between-session paired discussions and journalling.

The research intent of this professional learning project was to consider ways in which writing can be used as a tool when considering professional leadership identity. Writing was used not as an individual, isolated task but rather as a collaborative, guided process - as 'writing conversations' - the exchange between self and other, with an uneasy acceptance that neither are ever fixed or fully known (Thomas, 2012). Ways of thinking about language and writing is critical in this methodology. This project opened for consideration and held in tension the following aspects of what it can mean to work as a writing organizations: What happens when the writing process is a collaborative, guided process? Is this an effective way to support and allow for thinking anew as an individual and a team? In what ways are questions critical in this process? What type of questions are most valuable and why?

Read more as we move along together. 


\section{Minor multilingual leadership writing: activating difference; allowing experiences of vulnerability, response/ability and commonality}

Let us create extraordinary words, on condition that they be put to the most ordinary use and that the entity they designate be made to exist in the same way as the most common object. (Deleuze \& Parnet, 2002, p.3)

The concept of minor languages draws on Deleuze and Guattari's $(2013,1986)$ work on 'minor literatures'. Such a minor literature is hyperbolic, meager, messy, multimodal, revolutionary, fussy, in-comprehensive writings, and a literature producing affects thus other, by interfering and provoking. A major literature on the other hand, is seen as writings written in an established official majority tongue aiming at conceptualization and identity: establishing and fixing meaning. A minor literature has three features. Firstly, the language that is used is affected by deterritorialization, thus stripped out of syntax losing all symbolism and signification. Further, everything is political; such literature recognizes that we are, as individuals, all connected to a political immediacy. Last, but not least, through minor literatures everything has a collective value of/and/with "assemblages coming into play" (Ibid: 1986, p. 27). This can be actualized, the way we see it, by the relational vitality and elemental complexity that marks the act/art of writing, as the embodiment of language. And to contextualize this to ECEC, a minor literature draws on language writing that can be real, unformed, intense material auto-bio-ethnographic expressions. Rethinking literature and/as language this way makes possible new ways of thinking ECEC leadership practices. Multiple practices of writing, as an act/art drawing on minor literatures, is a multilinguistic that makes visible the possibility of translocal and corpovirtual ECEC thinking and doing. And through this is enabled new ways of thinking minor - or rather writing - as in multilinguisity - allowing more and other - for inclusion and learning. Writing languages, as we have seen... languages that write. We motivate eachother. We are eachothers' potentials. We are eachothers' responses and make possible eachothers' response-abilities. Vulnerable, fallible and together we response and see anew: Things we see and things we don't; Things we think and things we take for granted; Moments (and things) we brush away too quickly sometimes... when we lack words or...

To work with and within minor literature/languages and ultimately in a Deleuzian "no-ology" (Deleuze,1990, p. 1) way, we re-craft words, we borrow and we adapt words to think anew and other, and to support a diffractive process (through writing) which can challenge and question often sadly inflated and taken-for-granted major languages. This process of "diffraction does not fix what is the object and what is the subject in advance, ... diffraction involves reading insights through one another in ways that help illuminates differences as they emerge" (Barad, 2007, p. 30). Every word and every concept which produces affects thus 'other', through practices of interfering and provoking (again Deleuze \& Guattari, 2013,1986), is a becoming means by which we engage with and move beyond our own unexamined experiences (or even beyond our own examined experiences). Thus such a move making possible a connectedness to the localized political immediacy (and again Deleuze \& Guattari, 2013, 1986) - a connection beyond self to 'the other': a response-ability that goes beyond just reflection. One such word, that we here have borrowed and adapted, is translocality which implies an engagement with "the dynamics of mobility, migration, and socio-spatial interconnectedness and insights from transnationalism" (Reinertsen, 2016, p.165). Through bringing this term to the ECEC organizational field we extend and expand on the use of the term to explore the potentialities of its underlying notions of both mental and physical mobilities, multiplicities, networks, flows, knowledges, intensities, signs, symbols, people and places, in deterritorialized leadership and writing processes that push, resist and put in continual flux the boundaries (once considered fixed) of our educational institutions (Reinertsen, 2016). What this possibilizes, the way we see this again, is turning ECEC organizations and organizational learning, through a move beyond critically reflective modes to corpovirtual and 
translocal writing and its use or workings, into immanent or rhizomatic smooth spaces in which leadership practices and ECEC practices work together in ways that enable every child to become. Leaders - adult and child -ultimately possibilizing each other. Our desire is to use writing to enable practices which are more-than 'critical reflection', which enable new thoughts and disturbances, un-known thoughts, that de-territorializes thinking and re-territorializes actions. In this way we hope to engage in the complexities of ECEC practice, and enable leadership which can think/work/be both with and beyond the identification of self in the local context, i.e. translocality. And our identities, as leaders, and processes of writing leadership are turned into a constant corpovirtual rethinking of self and other, and our entangled togetherness - a collective entanglement. When we sculpt, layer and flow our thinking and writing with translocality and corpovirtuality we thus position identity/leadership, through multilingualism, as a minor language for leadership practices and its im/possibilities. In this way writing with/in a minor language allows for a process of keeping the concept of what we want (read response-ability in leadership and the gifts we want to give) and/but not giving it in advance:

to keep its concept, which is for writing what self-consciousness is for persons, sealed in its practice, it might perform the symbolic act of instancing a subjectivity that is not given in advance and that is more permeable to its textual and social environments than is customary in our critical language games. The embodiment of these possibilities may be the most powerful thing critique can accomplish today. (Levinson, 1998, p. 284)

Working to rethink the known and the un-known of leadership practices and professional identity through the use of leader supported critical writing - we work to enable an experience of localization of ECEC theories, principles and frameworks. We work with critical collaborative writing as a diffractive process of thinking and analysis to move the gaze of the leader beyond a focus on the self as a fixed and known entity, and allow a flow of the translocal in the workings of ECEC organizations. And to be clear: With this comes a requirement of the corpovirtual as utopian or fabulating and experimenting with order and disorder in which provisional and partial taxonomies are formed, but are always subject to change and metamorphosis, as new connections spark among words, bodies, objects and ideas... - possibilizing, moments of powerful leadership.. our gift...our languages... our post/responsibility and what we must. Our exploration of the conceptualization of translocality in the work of writing in and for leadership is presented in the following six extensions and erosions. It is our desire/gift to draw on the re-crafted concept of translocality to present some possibilities of leadership and writing with/in ECEC organizations.

First, translocality, enacted through practices of writing, serves as a fruitful starting point from which to challenge dichotomous conceptions of structures, regulations, rules and/or policies and in so doing question often taken-for-granted practices and representations of self. In such practices of writing can be seen the either/or questions we often ask ourselves about our practices and about ourselves, as we see in the extract from the Australian erosion below:

The binaries/dichotomies identified in the interview statements:

Am I doing a 'good job'?/What is a 'good job'?

$(I ' m)$ expected to 'know the answers'/sharing my uncertainty

What you want the role to be/what you know it has to end up being Importance of 'team'/wanting to be a 'loner' - is there room for individuality? Pushing others out of their comfort zone/resisting doing this myself My professional identity/it's not just about me

For Nel the opportunity to write collaboratively in response to the identified dichotomies was significant for her as she thought through and questioned her own identity as a leader and her engagement with the team: 
... what helped me in terms of understanding my professionalism was being able to define the role (of leader) for myself and then having to define it as a team (through the shared writing exercise)... when we 'laid out' the dichotomies (the written extracts from individual conversations) and had a look at those, that was tremendously helpful in (me) not feeling alone in my sense of conflict over so many different things ... and I think working collaboratively as a team on that and the conversation that we had (individuals writing comments in response to the extracts, followed by group discussion on everyone's comments) ... was really helpful in establishing "Okay, as (a professional group) we're understanding our professional identity", which enables me to do that much more effectively (Nel, 18.2.15)

From the Norwegian erosions there was the experience of allowing leaders to step out of controlling situations. Writing can thus create a space for deconstructing practice:

The way we see this, leadership is about creating arenas for deconstructing thus thinking new about our own practices, ECEC institutions and ourselves. We did not know that we were capable of creating knowledge ourselves. We thought we had to get hold of it outside our kindergarten. Now we see that through writing we create productive knowledge with and for ourselves and our own development (Holly,10.09.15).

Through questioning and deconstructive approaches, writing becomes a constant production of knowledge, a thinking with and creation of knowledge. It becomes a constant opportunity to ask questions and poeticize every word to expand contents and deepen analysis.

"The Question" - a poem - remains a testimony, in a dream, to the ghostliness of the present: a poem can no more be a gift, perhaps, than can a dream. But for just this reason the poem and the dream become privileged figures for trying to think about the gift. (Derrida, 1998 cited in Royle, 2003 p. 140)

Second, translocality enhances explicit discussion (read shared writing) of the temporal dynamics, path dependencies and time-space inter-/intra- connections and dynamics offering nuanced perspectives on differentiated forces in flows and movements. Leadership becoming creating intergenerational awareness about what signifies a child, an adult, a profession, education and more: making choices and taking responsibility for that which is good: response-abilities - ethics and localized politics. And again, keeping the concept of the gift and the beauty... duty...responseability....we want to protect... There are sensations, touches and dizziness...; care and recklessness confusion...; polyphone multi identities...; text layers upon text layers...; the messages in the mess somewhere...; constant recompositions with bodies and galleries of presences ...; mapping and tracing...; ontological insecurities: Diagrammatic methodologies of constant ruminations producing and questioning meaning and promoting transformative practices that become rather than answer. Writing that allows for complex encounters of/as micropolitical actions opening, privileging and yet a wondering that gifts a shared response-abiltity...

What we discovered was that as time went by we became very touched by what we had written. We had very strong feelings connected to our experiences in practice. Both when something happened but also when we spoke about it. We cried! Why were we so upset? Why were we so enthusiastic? Without finding any answers, still we sat wondering about what happened to us; what goes on in this room, now, between us in you and in me? (Holly, 10.09.15)

Third, translocality directs attention to alternative cartographies of leadership and pedagogies. Thinking new thoughts about what this place/plane/collective (Deleuze \& Guattari, 2013) - ECEC - is 
- is not. Writing - becoming a tool for leadership work that is focused beyond the self creating pedagogies from and with not easily found concepts. And through this, narrating moves from the personal to the political and writing up stories to think with: leadership seen as activism as writing. This is the construction around our projects ultimately unwrapping wrapping unwrapping quality and inclusive education, learning and play... Further, around applying writing as a method to analyze the practice of writing as a critical inquiry and reflection, meta-perspectives including therefore also Louise and Anne both. Thus flows and sculpts our working, diversely located and contextually constructed, memories...as learning and writing to give life to our thinking, our wondering, our possibilitizing ... our knowings, our unknowings and our not-yet-knowns, as we engage with the data and the data engage with us (Thomas, 2016).

So we continued writing about what we were part of and how to succeed in practice. And we worked a lot with children's voices, and about being sensitive towards every child. As time went by we saw that there were many different things we could work with. And gradually we linked our writing to the GWPs that regulate all ECECs in Norway and the leadership-contract with our local municipality. In the beginning we wrote about what we succeeded at, but gradually we started speculations and wonderings about what we were doing actually was in line with the intensions we work for? And I think we felt that what we wrote actually broke with the intentions. That which is at the executive level that is, and a commitment for working in ECECs in the first place. And that was exiting and it opened up perspectives and possibilities about thinking differently about us.... Finding out more about what we are doing, and can we recognize it as learning? Can we define it as learning? Or reducing it as learning... (Holly, 10.09.15)

I think the session we did as a team when we had the pieces of paper out and we all made comments on some of the things you'd taken (written) from the individual sessions (was) quite enlightening ... I think that (the reflecting on written extracts, individual responses and group discussion, followed by individual and paired reflection and individual journalling) was a good way for us to actually 'nut out' what we felt was important ... and be quite open and honest about that, because ... often we're all working (in) the same direction and thinking the same people presume that not the case. (Interview with ECEC leader, Emma, 18.2.15)

I think the (writing) activity that you got us to do (writing) on what we had said in our individual meetings (...) with you, I think that was the most, not confronting, but informative... It was like a 'light bulb moment' because it was 'wow, is that how some people perceive this thought', or 'I didn't know someone felt like that'. And that was powerful, but it was probably the most uncomfortable as well. ... That goes back to my theory of 'you have to be out of your comfort zone sometimes. (Interview with ECEC leader, Ann, 18.2.15)

No, no, no 'the tool' (the final written document) is definitely not any use without the process (the shared writing that led to the tool) ... it's just words without what we have been through, so to have those discussions (about the written words) and going back and forth and listening. (Interview with ECEC leader, Kay, 18.2.15)

The collaboration in the writing process was a key element in what was positioned as opportunity for leadership work to move beyond a focus on self as a fixed entity and practices informed by the already-known, to leadership flowing through lines of flight shaped in and from the not-yet-known self. 
Fourth, translocality highlights the importance of ECEC organizations as networked places of semiotics, thus languages and writing again. It is an in the middle-of- entanglement - minor moments - events and small thing writing. Choice is turned into a basic component of the materialsemiotic process. Providing a stable, but never fixed nor constant, infrastructure for openness where potentiality emerges as a powerful force for adaptation and evolution always more always other. Concepts expressing no beginning and ending events: Realities consisting of qualities in contemplating constant change, and subjectivity sensed as a force preventing randomization. And eventually to theorize with Deleuze and Guattari (2013), this translocal place and ECEC is rhizomatic:

A rhizome ceaselessly establishes connections between semiotic chains, organizations of power, and circumstances relative to the arts, sciences, and social struggles. A semiotic chain is like a tuber agglomerating diverse acts, not only linguistic, but also perceptive, mimetic, gestural, and cognitive: there is no language in itself, nor are there any linguistic universals, only a throng of dialects, patois, slangs, and specialized languages. (Deleuze \& Guattari, 2013, p. 6)

We have developed a richer language that I think contributes big time to our practices. Our conversations are marked with something different than before. Then we talked about who does what. We have moved from an almost didactical way of speaking to wondering about contents. And we try to place ourselves in a theoretical framework. It is almost as if that has become an urge of ours. (Holly, 10.09.15)

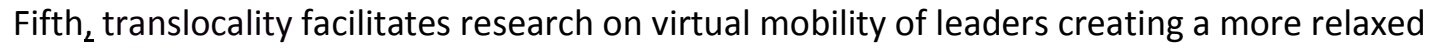
atmosphere and acceptance for utopian thinking and fabulation. Gifts perhaps... Creating thoughts about what we might replace in our current realities with realities we truly want.

I think of myself as leader in counseling. What might be different from regular counseling is that our paths are created as we walk them. I must dare that the future is open for us. (Holly, 10.09.15)

These are writings and/as aspects of autobiographical and auto-ethnographical performances. Writing becoming a method for inquiry and the hub in/of our machinic enthusiasms: Fiction as method. Writing ourselves and others acting as "writing subjects" (Reinertsen, 2015, p. 285-290). Storying events about power and performances, and micro mobile and non-localized connections: Some/thing/s without languages and/or/but always new starting points.

Finally, by placing an explicit emphasis on local conditions, translocality draws attention to transformations of the physical and natural environment. In so doing, translocal research and writing can engage in the discussion on intra-intergenerational interdependencies ultimately global environmental change and strengthen the importance of mobility, concepts and resources within the real/virtual debate: A writing about a preparing or preparedness for future contingent events. Again; it is a utopic way of thinking and (im)possibilizing the gifts of leadership and writing in a meta meta meta perspective telling us something about stakes and risks of not.... -and minor again knowing and giving... micropolicies and practices in hybrid spaces perhaps; aporetic imaginings of leadership. Always troubling any measurements and sticking with unstable tools: Re-writing leadership and/as vulnerable knowing. And through/with such leadership, constant re-writings of (non)contextual pedagogies.

In the beginning there was resistance. But we make time to think differently than what we used to do. Can the ECEC be different than what we have thought it to be before? Can you be different than what you have thought you are? Can the child be something else for you tomorrow than what it is today? Writing is risking increase in value. Practice increases its 
value through writing. That is because you discover things that are new to you and this in turn releases pictures in you from the ECEC that you perhaps did not know existed. This happens while you discover your own value. The little I do gets increased value (Holly, 10.09.15).

Major/minor/must translocal critical de- reterritorialization constant becomings becomingness and us/of ours...

\section{Becomingness of language through writing}

The constant becomingness of language, made material through writing is a key contributor to leadership practices which work with both the known and not-yet-known of self and other.

Deterritorialisation and reterritorialisation are at work in and through the becomingness of language

- "deterritorialisation occurs when an event of becoming escapes or detaches from the original territory" (Colebrook, cited in Jackson \& Mazzei, 2012, p. 89). Writing, and more writing after writing, involves a deterritorisation and a reterritorialization of words and language. Words, as the material embodiment of language, are rich, complex, constant, and fluid and contextual. When we attempt to write about writing this richness, complexity, constantality, fluidity and contextuality present both challenge and opportunity, and a must-be-striven-for impossibility. If language is a writing tool used as a process of exchange between self and other, both of which are never fixed and always becoming, each step in the writing process - from self to other - involves deterritorialisation - i.e. one force acting on another force in the process of becoming - such that the forces are no longer what they once were - diffraction. This can be applied to the writing process involved in mentoring/guidance for a process of diffractive engagement between "self" and "other" (and to the process of writing when engaged in shared authorship of written work). The challenge and opportunity, and impossibility we take up in this article are driven by a two-fold desire to share our constantly becoming thinking about writing as a tool to firstly, support leadership in ECEC contexts and secondly, to examine leadership processes at work in ECEC organizations. In pursuing the enactment of this desire we experience deterritorialisation of the concepts of writing and language that enable us, and at times constrain us, as we re-think how the writing of words works and in what ways the matter of writing matters. We also experience writing as a leadership tool that involves an openness to reterritorialization of words and language. Our exploration of these experiences of deterritorialization and reterritorialization make possible opportunities to think and act with the material pedagogical practices of ECEC and material leadership practices in ECEC organizations in new and constantly becoming ways.

Being our own examples as writers, and thinkers and questioners of our own writing and the matter of writing, our exchanges show the practice of writing is multi-layered.

Dear Anne, writing is constructed across and through variously engaged layers and multidirectional shifts, e.g. notes in margins of other people's writing, as I engage with what I think is their meaning and in this process construct new meanings from their work; notes and scribblings in my notebook (yes real paper and an old fashion pencil!) as I attempt to develop my own thinking and re-present this thinking into words I can share; writing-up this thinking through an email to share with my co-writer. In our entangled togetherness you and I - and all that we engage with - are writing, re-writing, shifting and layering, folding and flowing our own words, our shared back-and-forth words, our not-yet-known words.

Dear Louise, something happens on paper when I write and it might not be what I thought ... and what I thought I was writing in my email. I write myself with an 'other' or perhaps I write myself with my not-yet-present self. In the other article that I wrote with Nina on leadership 
for quality for this special issue of RERM, I use the same data as I use here but it changes - and I do - just as you have written about before in your article on "Data as constant becomingscollapsing dichotomous divides of data and researcher in identity construction work" (Thomas, 2016, p. 41). Contexts, theories, practices, reflections, diffractions and people matter as we plug in again and again. Also, one article is written in Norwegian the other is English and translations..., you know, are tricky, playing tricks on all of us I think. I once wrote an article on teachers as translators and language workers instead of calling us knowledge workers. I think we all are.

All writing thus seems to be a/our process/es of mapping and tracing - thoughts, words, acts - and any act of writing - done for the purpose of newness, muchness and more ...- is a becoming, an engagement with other, even if that 'other' also is a new-always-becoming self. Writing, as nothing but assemblage which works in and on itself, as processes of deterritorialisation/re-territorialisation, is "always multiple and composite" (Deleuze \& Guattari, 2013, p. 592).

And then we ask: at what point is writing and the meaning you give to your words/writing no longer yours? What happens when it is shared with another - as a gift; performed to an audience - as a performance? When language/words/writing you construct is 'given' to/performed for another, is it open to lose the meaning you assigned? Rather than think of 'meaning lost' is it possible to consider meaning as a becoming assemblage - the giving/performing of language, through writing? Can thinking of writing in this way strengthen the capacity for leading thinking anew and thinking with and through difference? That is, using collaborative performative writing in a way that moves beyond an acceptance of reflective practice that focuses on the already known to a practice of diffraction which focuses on the 'in-between' self and other; the unknown and unknowable spaces in the self/other relational culture of ECEC organizations - a diffractive process that allows for multiple folding back over the know of self to allow for new looking and new thinking in ways that make it unknown. In their discussion of ethnographic writing as a performance, Ellis and Bochner (cited in Denzin, 2010, p. 29) suggest that "the writer-as-performer is self-consciously present, morally and politically self-aware. She uses her own experiences in a culture "reflexively to bend back on self and look more deeply at self-other interactions" ". Once 'given', does language and writing become open to the possibility of new meaning constructions? Constructions that are minor mine, unformed intense material expressions opening up glimpses of insights, wisdom 'perhaps' for leadership, and in this way connecting the construction of writings and the act of unknowing self as a necessary part of any connection between self and other. But also constraining the possibility of such connection due to the impossibility of giving a fixed meaning through writing - the impossibility of certainty in any gift and giving... Writing is/ as gift ....Gifts without Giving... Bodies without Organs and Writing without Meaning... GwG/BwO/WwM/... gifts that have no expectations or conditions and which are never owned and can never be given ... And again: Cixous (2005), hidden secrets that could make me go wrong but still opening up for me to go on ...

\section{Writing and leadership as performance and the impossibility of gift}

Writing forward, as we sculpt and fold the flows of our thinking on writing matters, we return to our point that what matters in both writing and leadership is the sculpturing, layering, flowing practices. Writing is not a practice of fixed meaning making but a performance (see Pelias, 2013, p. 560) that flows and shifts and surveys and maps between self and other: a performance between self and other - where the performance is an impossible, unknowable gift and at times the 'other' is a notyet-known self. Thus writing allows for being/thinking other than what you once were/thought. Leadership, which is at work through and in such writing practices, is a performance (an impossible gift) - a constant becoming; an immanence which resists any fixed expectations of leadership 
practices and flows with possibilities precisely because of its impossibility. Writing and leadership are positioned as performance and gift.

Do we engage with writing, as performance, to learn something that is already or to think in new ways, to think about things yet to be known, to think differently about what was thought to be certain? We argue that writing is necessarily a voyage into the unknown - the reader (whether other external to the self or a new self formed as a result of the writing) takes the writing to unknown, notyet-known, ways of thinking, speaking and being. We write/lead not to present answers but to open opportunities for deeper questions and to allow for uncertain and constant becoming wonderings. This requires a particular type of writing and leading, writing and leading that are focused on the performance of becoming rather than the certainty of being. In this way of theorizing writing, it can be positioned as performance such that it enables what Denzin (2010) refers to as a methodology to link "critical pedagogy with performance autoethnography" (p. 30). As such "performance (for us, writing) is a way of knowing (for us, knowing leadership), a way of creating and fostering understanding (s), a method that persons use to create and give meaning to everyday life" (p. 30). However, describing such a methodology, Denzin (2010) identifies performance writing as a genre "that blurs the edges between text, representation and criticism" (p. 29) and draws on the work of Pollock (cited in Denzin, 2010) to position performative writing as "always incomplete" (p. 124).

For us, writing can be seen as a methodology which performs and makes available to the writer a becomingness that is constantly other. Pelias (2013) suggests that writing is "a performative act, a material manifestation of a writer's labor and ideology" (p. 560). He presents three examples of possible methodological strategies available to researchers to foreground their work (the curative, the citational corrective and the socially consequential). His elaboration of the writing strategy that foregrounds the "socially consequential" suggests that what is possible through such writing-up of research is a presentation of "alternative social constructions and practices" (Pelias, 2013, p. 561). We argue that ECEC educators and leaders who engage in collaborative and diffractive writing, as researchers of their own practices/labors and ideologies, could be seen to be drawing on a writing strategy that is a variation on Pelias' third example - the professionally consequential. In this way leadership, embodied through the act/art of collaborative and diffractive writing, can make available to (gifts to) ECEC educators - alternative professional constructions and practices.

Dear Louise, I think it is very difficult not to say no-thing about leadership, so I say a lot. However, what I try is to minor do it without sledgehammers as Deleuze and Guattari ask. I try to throw words as bricks through windows as they also at one point in The Thousand Plateau book ask. But it is challenging as in paradoxical and/as a morale. I forget. I make mistakes. I tell. I do not know what gifts to give... or rather I give...

And to say just a few more words about corpovirtuality and the self, because it helps:

The ethnographical life is not separable from the Self. Who we are and what we can bewhat we can study, how we can write about that which we study- is tied to how a knowledge system disciplines itself and its members, its methods for claiming authority over both the subject matter and its members. We have inherited some ethnographic rules that are arbitrary, narrow, exclusionary, distorting, and alienating. Our task is to find concrete practices through which we can construct ourselves as ethical subjects engaged in ethical ethnography- inspiring to read and write (Richardson \& St. Pierre, 2005, p. 965).

Dear Anne, could an example of these concrete practices be critically reflective writing going beyond 'self'? If the writing/leadership at work in the practice of self-questioning and thinking anew is a performance, then it requires consideration to be given to both the performer and the 
audience. As a writer/leader I have a response-ability and that response and ability is to give, but there can be no giving if there is not an 'other'.

Dear Louise, there is always an-other. And critique as reflective or rather diffractive thinkingfeeling and writing is built-in. I do not speak of criticism but critique (Reinertsen, 2011). The way I see this, rethinking or rather forethinking leadership as a collaborative and vulnerable process of writing is moving beyond leadership taking into account complex inter-intra relations that shape emergent processes of organizing and change. It is per se a move away from ideas of individual agency and control. Traditional concepts of hierarchy, selective application, linearity and rationality are no longer appropriate. There are always different shades and elaborations. None are complete or finished. The authority of the reader and audience is pivotal. Without it these are just dead written words. Words perform. They must. They are performances. If any gift at all this might be something... In bodies without, the without is the most important.

Dear Anne, yes and ... just as with any writing through which words perform and so the audience/reader is pivotal, so too with leadership - leaders perform and, in the same way with writing, the audience (the participant) is pivotal. The agency of the audience is what gifts life and meaningful becomingness to any performance/leadership; a gift of response-ability.

\section{Forethinking gifts opening up for a glimpse of powerful leadership and response/ability}

The gift is mad. It is a madness. Like differànce (Derrida, 1994. p. 27).

The gift is that which one does not have (Derrida, 1994, p. 27).

So when, inspired by Cixous (at the introduction of this article) and Derrida (above), a gift is given it is always a gift without: a gift always, but not: Always under erasure and always after the trial and experience of aporia or this necessary aporetic analysis of gift and thus duty, both double and single or rather an "over-duty" and thus action (read writing) undertaken "out of the sense of duty" and therefore (in agreement with Kant) as the very condition of morality (Derrida, 1993, p.16). And again, that again is our duty, responsibility - and response-ability - and gift.

This paradoxically implies an impossibility of speaking particular discourses of leadership into existence through the gift of writing, but an opportunity of viewing writing as a construction/deconstruction/reconstruction auto-ethnographical accountability process to self and other through gifting of response-ability. Further this enhances the importance necessity/responsibility of writing about writing for leadership/as leadership/in leadership. The real gift/leadership - becoming the unknown and the uncertain, and writing becoming a gift/a leadering to self and to an-other? Such writing is for all of us; with all of us.

Many of the participants discover something new about own thinking! It opens something up and we continue. Write down what you think now! Something happens in us when we write. Not in all of us, but in many... -getting your thoughts in front of you. The written word has more authority, and can be scarier. One might ask: Wow, am I committed to relate toand do what I have written? We have talked a lot about that, and the fact that we write here and now: Today it is exactly this that I think. Tomorrow I probably think differently. What I think is only in this moment. That is how I think about it/something today. Practice is moving and therefore we cannot be static in neither our writing nor our thinking. Everything is weaved into other thoughts and texts (Holly, 10.09.15). 
Dear Louise, salient John Dewey taught us that democracy is more than a political system. Rather it is a way of living. Democratic leadership as a way of living... - life... I think of immanent as in life leadership. If that is in any way thinkable at all, I think... getting my thoughts in front of me.... that might be my response-ability and gift. Democracy/writing mattering... The way I see this, it is a withness of child and becoming, - an apparatus of empowerment. I am futuring glimpses of powerful leadership.

Dear Anne, and to add to this, writing/leadership matters not in the doing but in the gifting/becoming; the opportunity for a response from the 'audience' (read reader/participant), the necessity of a response from the 'audience', the ability of a response from/with the audience... the way I see it, a withness of self and other - an ethical corpovirtuality of leadership, powerful leadership - made powerful precisely because of its gifting to other, its giving: powerful leadership without power.

\section{References:}

Barad, K. (2007). Meeting the universe halfway: Quantum physics and the entanglement of matter and meaning. Durham: Duke University Press. http://dx.doi.org/10.1215/9780822388128

Barad, K. (2012). What is the measure of Nothingness? Infinity, Virtuality, Justice. 100 notes-100 Thoughts-100 Gedanken. dOCUMENTA (13)9/6/2012-16/9/2012. Erschienen im Hatje Cantz Verlag. Germany

Cixous, H. (2005). Stigmata (in French) (E. Prenowitz, C. A.F. MacGillivray, \& K. Cohen, Trans.). London, England: Routledge. (Original work published 1998)

Deleuze, G. (1990). The logic of sense. (Trans. M. Lester, C. Stivale, \& C.V. Boundas (Ed.). New York: Columbia University Press.

Deleuze, G. \& Guattari, F. (1986). Kafka: Toward a minor literature. Trans. Polan D. Minneapolis, MN: University of Minnesota Press.

Deleuze, G. \& Guattari, F. (2004). Anti-Oedipus: Capitalism and schizophrenia. London, New York: Continuum.

Deleuze, G. \& Guattari, F. (2013). A thousand plateaus: Capitalism and schizophrenia. London: Bloomsbury Academic.

Deleuze, G. \& Parnet, C. (2002). Dialogues II, Columbia University Press. New York.

Denzin, N. K. (2010). The qualitative manifesto: A call to arms. Walnut Creek, California: Left Coast Press.

Derrida, J. (1993). Aporias. CA. Stanford University Press.

Derrida, J. (1992). The other heading: Reflections on today's Europe. Bloomington \& Indianpolis: Indiana University Press.

Derrida, J. (1992). Given time. Chicago IL: University of Chicago Press.

Derrida, J. (1994). Specters of Marx: The state of the debt, the work of mourning, \& the new international. New York and London: Routledge.

Jackson, A. Y. \& Mazzei, L. A. (2012). Thinking with theory in qualitative research: Viewing data across multiple perspectives. London and New York: Routledge.

Janesick, V. (2016). Poetic inquiry: Using found poetry and identity poetry to transform qualitative data. In A. B. Reinertsen (Ed.) Becoming earth: A new materialism turn in educational discourses collapsing nature culture divides or greenish post-anthroposcene humanities. The Netherlands: Sense Publishers, (pp. 31-40). http://dx.doi.org/10.1007/978-94-6300-429-9_4

Kierkegaard, S. (1994). Avsluttende uvidenskabelig efterskrift til de philosophiske smuler. Fagernes: Pax Forlag.

Levinson, M. (1998). Posthumous critique. In N.B. Dirks (Ed.) Near ruins: Cultural theory at the end of the century. Minneapolis, MN: University of Minnesota Press, pp. 257-293. 
Pelias, R. J. (2013). Writing into position: Strategies for composition and evaluation. In N. K. Denzin \& Y. S. Lincoln (Eds), Collecting and interpreting qualitative materials. Thousand Oaks: Sage, pp. 547-568.

MacLure, M. (2013). Researching without representation? Language and materiality in postqualitative methodology. International Journal of Qualitative Studies in Education, 26 (6), 658-667. http://dx.doi.org/10.1080/09518398.2013.788755

Reinertsen, A. B. (2011). DDD + assemblage community not and youto(o)biography? International Review of Qualitative Research, 2(2), 247-268.

Reinertsen, A. B. (2015a). Uten store ord - Autoetnografisk etnometodologisk 3D skriving. I Metodefestival og øyeblikksrealisme. In A. M. Otterstad og A.B. Reinertsen (Eds) (pp. 266295). Bergen: Fagbokforlaget, .

Reinertsen, A. B. (2015b). A minor research and educational language: Beyond critique and the imperceptible beingness of engagement; creating spaces for collective subjectivity intensities, for change, and for social justice Qualitative Inquiry, 21(7), 623-627. http://dx.doi.org/10.1177/1077800414555074

Reinertsen, A.B. (2016). A Phaedrus baroque art of maintenance or constant fabulating qualia becoming quality. Contemporary Issues in Early Childhood. Special Issue: Re-imagining quality in early childhood. 17(1), 112-123 http://dx.doi.org/10.1177/1463949115627909

Rhodes, C. (2001). Writing organization: (re)presentation and control in narratives at work. Amsterdam: John Benjamins Publishing Company. http://dx.doi.org/10.1075/aios.7

Royle, N. (2003). Jacques Derrida. London and New York: Routledge. http://dx.doi.org/10.4324/9780203380376

Richardson, L. \& St. Pierre, E. A. (2005). Writing: A method of inquiry. In N. K. Denzin \& Y.S. Lincoln (Eds), Handbook of qualitative research (pp. 959-978). Third Edition. Thousand Oaks, California: Sage..

Thomas, L. M. (2016). Data as constant becomings-collapsing dichotomous divides of data and researcher in identity construction work. In A. B. Reinertsen (Ed.) Becoming earth; a new materialism turn in educational discourses collapsing nature culture divides or greenish postanthroposcene humanities. (40-51). The Netherlands: Sense Publishers.

Thomas, L. M. (2012). New possibilities in early childhood teachers' professional identity constructions and ethics. Australasian Journal of Early Childhood, 37(3), pp. 87-95. 